\title{
Solusi Sosial atas Kontestasi Agama Mayoritas-Minoritas di Arjawinangun Cirebon, Indonesia
}

\author{
M. Yusuf Wibisono ${ }^{1 *}$, Akhsin Ridho ${ }^{2 *}$, Ahmad Sarbini ${ }^{3}$, Dadang Kahmad ${ }^{4}$ \\ UIN Sunan Gunung Djati Bandung, Indonesia; m.yusufwibisono@uinsgd.ac.id \\ 2 Institut Agama Islam Negeri Jember, Indonesia; psi.iain.jember@gmail.com \\ UIN Sunan Gunung Djati Bandung, Indonesia; ahmadsarbini@uinsgd.ac.id \\ 4 UIN Sunan Gunung Djati Bandung, Indonesia; dkahmad1@yahoo.com \\ * Correspondence
}

Received: 2020-11-23; Accepted: 2021-03-08; Published: 2021-04-08.

\begin{abstract}
This research aims to see that the existence of minority religions in Arjawinangun is very much considered part of the life of the majority religion. The majority religion's protection is intensely felt by minority religions as a form of religious tolerance and highly appreciates differences to become the primary capital of economic, social, and religious development in their communities. This study examines society's sacred theology, the approach, and the method used in social change. This type of field research uses descriptive qualitative analysis. The study results can be argued that: Religious plurality is the basis for people's attitudes to accept and respect other religions. The community has a moderate attitude towards the existence of religious anti-pluralism and pro-pluralism groups. The conclusion is that religious pluralism becomes a means to the common good in solving humanitarian and national problems. Based on the modern, pluralistic social considerations with its religious typology, it is the theology of religious freedom due to charismatic pluralist religious figures' influence.
\end{abstract}

Keywords: Charismatic plurality; harmony theology; minority-majority religions; religious freedom.

Abstrak: Tujuan penelitian ini adalah melihat eksistensi agama minoritas dalam keberagamaan di Arjawinangun sangat diperhatikan sebagai bagian dari kehidupan agama mayoritas. Pengayoman dari agama mayoritas sangat dirasakan oleh agama minoritas sebagai wujud toleransi beragama dan sangat menghargai perbedaan sehingga mampu menjadi modal dasar pembangunan ekonomi, sosial dan agama di masyarakatnya. Penelitian ini mengkaji tentang teologi keagamaan masyarakat, pendekatan dan metode yang digunakan adalah perubahan sosial masyarakat. Jenis penelitian lapangan dengan analisis kualitatif deskriptif. Hasil penelitian dapat dikemukakan bahwa: Pluralitas keagamaan menjadi dasar sikap masyarakat menerima dan menghormati agama lain. Masyarakat memiliki sikap moderat atas eksistensi kelompok anti-pluralisme dan pro-pluralisme agama. Kesimpulannya adalah pluralisme agama menjadi sarana menuju kebaikan bersama dalam menyelesaikan masalah kemanusiaan dan kebangsaan, berdasarkan pertimbangkan sosial modern yang majemuk dengan tipologi keagamaannya adalah teologi kebebasan beragama akibat adanya pengaruh tokoh agama yang pluralis karismatik.

Kata Kunci: Agama minoritas-mayoritas; kebebasan beragama; pluralitas karismatik; teologi kerukunan.

\section{Pendahuluan}

Agama menjadi ruang privat tersendiri yang menjadi bagian dari pengekangan yang dilakukan oleh kekuasaan (Wigger, 2019). Pada faktanya, ketika kran demokrasi dibuka, masyarakat yang mengidamkan sebuah keyakinan agama dengan ciri dan kekhasannya sendiri, seolah mendapatkan ruang dan angin segar untuk mengaplikasikannya. Semangat untuk menyuarakan keyakinan di tengah masyarakat tersebut merupakan bentuk penunjukan identitas. Seolah ingin meneriakkan, bahwa inilah 
aku dengan segala keunikan dan keuniversalan keyakinan (Crome, 2019). Bahkan ruang kebebasan tersebut seolah menjadi medan pertarungan untuk mengajak kepada yang lain agar turut serta menjadi bagian darinya, hal demikian merupakan politik identitas keagamaan (Umam, 2018, hal. 163).

Perkembangan Islam di Indonesia, mengalami akulturasi secara intensif, ditandai oleh adanya semakin tolerannya masyarakat dengan etnis atau agama lain yang berbeda (Armini, 2017; Casram, 2016; Erwantoro, 2012). Dengan demikian, dalam berbagai hal kegiatan keagamaan, banyak diwarnai oleh ciri-ciri agama lain yang melekat. Oleh sebab itu, bagi masyarakat desa secara umum dan khususnya di wilayah Kecamatan Arjawinangun Kabupaten Cirebon, sebagian dari masyarakat tampaknya masih memiliki suatu model keyakinan di luar standar agama yang diyakininya (Hariyanto \& Bsi Bandung, 2016, hal. 214). Perubahan tersebut membaur dalam kerangka kehidupan sosial yang saling menjunjung tinggi nilai-nilai budaya yang ada di masyarakatnya.

Arjawinangun, adalah salah satu contoh sebuah wilayah kecil di Indonesia yang terletak di Kabupaten Cirebon Provinsi Jawa Barat, yang telah sejak lama dihuni oleh beragam etnik, budaya, dan agama. Islam, Kristen, Budha dan Tionghoa telah lama hadir di tengah-tengahnya, juga di akui mempunyai peran besar dalam menciptakan kerukunan dalam kehidupan sosial masyarakat yang harmonis (Haryono, 2017, hal. 216). Di tengah isu-isu konflik antar etnis, budaya, dan agama yang terjadi di berbagai daerah di belahan bumi Indonesia yang terjadi silih berganti, Arjawinangun terbukti masih tetap dalam suasana kehidupan harmonisnya (Manfaat, 2013, hal. 35).

Fakta otentik juga dapat dikenali bahwa agama mayoritas yang dimiliki oleh setiap bangsa di dunia ini berimplikasi logis terhadap agama para minoritas dan sering kali menjadi alasan dalam mengambil tindakan ketika berkuasa (Mikles, 2019). Potensi agama minoritas dan mayoritas di Arjawinangun sendiri dijadikan modal sosial untuk membangun kekuatan bangsa demi mencapai kesejahteraan. Agama minoritas juga sangat berperan dan bersinergi dengan agama mayoritas dalam kehidupan di masyarakat. Komunikasi yang efektif memberdayakan mayoritas maupun minoritas untuk produktif, inovatif, dan kreatif. Penyebaran kesepahaman tersebut berpengaruh besar pada dinamika kehidupan masyarakat yang ada di dalamnya (Maryam, 2013, hal. 45).

Agama minoritas kini telah menjadi isu global, diperbincangkan di berbagai forum dunia, dianalisa oleh berbagai peneliti juga sering dijadikan salah satu objek kebijakan yang penting dari negara-negara barat (Eisenberg et al., 2009; Long, Rahman, Razick, \& Salleh, 2017; Putra \& Wagner, 2017; Ruane, 2006). Namun demikian patut disayangkan bahwa naiknya isu minoritas yang tertindas ke panggung dunia tersebut lebih dipengaruhi oleh faktor-faktor yang sejatinya bertentangan dengan ide dasar dari pluralisme agama, yaitu adanya kekerasan dan intoleransi (Nursa'adah, 2018, hal. 24). Seperti kita ketahui banyak peristiwa konflik agama, terutama yang terjadi dalam tragedi kemanusian atas nama agama mayoritas. Peristiwa yang paling banyak melukai kalangan minoritas, apakah dia Islam, Kristen, Hindu, Buddha, atau Konghucu, sering menjadi alasan agama mayoritas untuk melegalkan arogansinya (Arwani, 2014, hal. 39). Karena perbuatan mereka itu, apa pun alasan dan motivasinya, jelas bertentangan dengan nilai-nilai moral agama mana pun di muka bumi ini (Mantu, 2015, hal. 131).

Arjawinangun mayoritas penduduknya adalah penganut agama Islam. Namun begitu, meskipun predikat sebagai mayoritas, sangat toleran terhadap minoritas (Maulana, 2017, hal. 17). Hal mendasar bahwa masyarakat tidak pernah mengklaim atas dirinya sebagai absolut (Rubin, 2019). Pola yang umum terjadi konflik adalah berawal dari anggapan sebuah kelompok yang menganggap kelompok yang berbeda agama dan aliran sebagai kelompok yang sesat (Macacfie \& Raphael, 1982). Istilah tersebut tidak hanya menyudutkan pandangan kelompok lain yang berbeda, tetapi juga menempatkannya sebagai yang keluar dari nilai kebenaran, dicap sebagai orang kafir, dan pada puncaknya dianggap sebagai orang yang halal darahnya untuk ditumpahkan. Oleh karenanya, dalam beberapa kasus, mereka yang mengklaim diri sebagai pemegang otoritas kebenaran, menuntut orangorang yang berbeda paham dengan mereka untuk menentukan dua pilihan yang sama-sama sulit, kembali kepada ajaran agama yang mereka anut, atau dengan seksama membuat agama baru (Ural \& Berg, 2019). 
Kejadian tersebut menimpa beberapa kelompok aliran dalam Islam, sebut saja seperti Ahmadiyah, Syiah, dan beberapa aliran yang dianggap sesat lainnya. Kelompok yang berbeda dari cara pandang keagamaan mainstream dianggap sebagai aliran sempalan yang keluar dari keyakinan pokok (Campbell \& Skinner, 1976). Tuntutannya agar mereka mengikuti paham yang sama dan tidak keluar dari keyakinan pokok agama. Jika tidak, justifikasi negatif, cacian dan bahkan kekerasan fisik menjadi taruhannya. Jika ditarik pada hubungan antar pemeluk agama, kejadian di atas dapat mengarah pada permasalahan yang lebih runcing lagi (Nuruzzaman, 2018, hal. 89). Beberapa kasus kekerasan atas nama agama pun kerap terjadi. Misalnya, kasus yang melibatkan kelompok HKBP Bekasi dengan warga sekitar, pembangunan rumah ibadah dengan pemkot Bogor, serta kasus pemukulan terhadap orang yang beribadah di Jogjakarta, bisa dijadikan beberapa contoh dari deretan panjang perilaku sewenang-wenang dalam relasi antar umat beragama di Indonesia. Dari beberapa kasus tersebut, bisa dilihat bahwa hubungan antar warga tidak lagi dibangun atas dasar cita-cita untuk kedamaian bersama melainkan dipaksakan dalam hal kesamaan agama dan aliran (Umam \& Ghazali, 2019, hal. 20).

Rumusan utama yang akan dikaji dalam penelitian ini berdasarkan deskripsi pada latar masalah di atas adalah untuk menganalisa karakteristik dan praktik-praktik keagamaan masyarakat dalam membina kerukunan antar umat beragama sebagai tawaran atas solusi dalam konflik di masyarakat plural. Khususnya karakteristik mereka dalam menjaga toleransi antarumat beragama, dimensi keagamaan dan bagaimana peran tokoh agama dalam internalisasi sikap toleran pada keberagamaan masyarakat tersebut.

Penelitian sebelumnya yang banyak membahas tentang pluralisme agama dapat ditemukan dalam karya penelitian dari Harold Coward, John Hick, Adnan Aslan, Diana L. Eck dan Nicholas Rescher. Fokus kajian penelitian mereka menyangkut gagasan tentang definisi dan arah dari maksud pluralisme agama sehingga dalam kajian mereka tidak sampai mereduksi keyakinan agama yang dianut oleh penganutnya (Aslan, 1998; Coward, 1985; Eck, 2001; Hick, 1985; Rescher, 2005). Beberapa tokoh di Indonesia juga banyak yang menaruh fokus kajiannya pada perkembangan pluralisme agama namun lebih spesifik dalam wacana Indonesia. Para cendekia tersebut misalnya, Budhy MunawarRachman, Jalaluddin Rakhmat, Husein Muhammad, dan Djohan Effendi (Muhammad, 2011; Rachman, 2010; Rakhmat, 2006; Sirry, 2003; Sumarthana, 1993; Taher, 2011).

Desain yang digunakan dalam penelitian ini adalah studi terfokus, yang dimaksudkan bahwa proses analisis data hasil penelitian difokuskan pada sebuah fenomena masyarakat di Arjawinangun. Selanjutnya, guna diperoleh data kualitatif yang kokoh, Instrumen utama dalam penelitian ini adalah peneliti sendiri sebagai instrumen. Teknik pengumpulan data dilakukan melalui observasi, wawancara, dan studi dokumentasi. Sebagaimana dimaklumi bahwa dalam penelitian naturalistikkualitatif, proses pengumpulan data harus dilakukan peneliti dalam situasi yang sebenarnya. Data yang diperoleh melalui wawancara dan observasi akan diperhalus, dirinci dan diperdalam. Data melalui wawancara dan observasi tidak segera dianggap kuat bila diperoleh hanya dari satu sumber. Oleh karena itu, setiap data akan terus dicek dan dibandingkan dengan data yang diperoleh dari sumber-sumber lainnya.

Pengumpulan data primer dari responden dan informasi dari informan dilakukan dengan wawancara mendalam dan observasi. Selain itu, untuk kepentingan pengumpulan data sekunder, baik teori, pandangan-pandangan, hasil penelitian, buku dan catatan-catatan, digunakan studi dokumentasi dan kepustakaan. Pendekatan yang digunakan dalam penelitian ini adalah pendekatan naturalistik-kualitatif dengan metode deskriptif-analitik. Proses kerja metode deskriptif-analitik menitikberatkan pada pemberian gambaran mengenai gejala-gejala atau peristiwa yang terjadi di lapangan secara natural dan yang paling aktual, serta melakukan analisis-kritis terhadap gejala-gejala atau peristiwa tersebut sehingga diperoleh makna yang utuh dari fenomena yang diteliti di lapangan.

\section{Sikap Keberagamaan Masyarakat}

Mayoritas agama yang dianut masyarakat Arjawinangun adalah beragama Islam dengan jumlah 69.166 orang dan tersebar di seluruh desa yang ada di kecamatan Arjawinangun lalu sebanyak 453 orang yang beragama Kristen Protestan bertempat tinggal di desa Jungjang, Arjawinangun dan 
Kebonturi kemudian sisanya sebanyak 13 orang beragama Budha dan tersebar di desa Jungjang dan Kebonturi. Untuk tempat ibadah memiliki buah masjid, 1 buah Gereja di desa Jungjang dan Wihara 1 buah dengan letaknya yang saling berhadapan di desa Jungjang ini mencerminkan kuatnya toleransi yang sudah mengakar kuat sejak lama diantara umat beragama yang ada di Arjawinangun.

Masyarakat perdesaan di Arjawinangun memahami pluralitas dalam arti menempatkan pluralitas sebagai keniscayaan dan realitas. Pluralitas adalah grand design Tuhan. Oleh karena itu, ia ada bersama adanya kosmik, maka tidak ada sikap lain bagi manusia kecuali menerimanya sebagai suatu keniscayaan. di dalam Islam penjelasan mengenai pluralitas tersebut berkaitan langsung dengan identitas antropologis manusia, seperti agama, etnis, masyarakat, bahasa, gender dan sebagainya. Hal inilah yang pada gilirannya mendasari munculnya sikap penerimaan terhadap pluralisme sebagai konsekuensi dari pluralitas.

Menerima dan mengakui adanya eksistensi agama lain tidak berarti mengakui bahwa semua agama sejajar; kadar dan kebenaran yang sama dan menempatkan segalanya dalam kerangka relativitas. Masyarakat perdesaan Arjawinangun tentang pluralnya keragaman agama tetap menempatkan Islam sebagai agama yang diyakini terbaik dari agama di luar Islam khususnya bagi yang memeluk Islam, sembari mengakui bahwa agama lain berhak untuk hidup dan berkembang. Setiap agama memiliki dan mengajarkan jalan keselamatan bagi setiap pemeluknya. Jadi, bagi masyarakat perdesaan Arjawinangun, secara eksternal keragaman agama tidak dipungkiri. Namun, secara internal Islam agama yang terbaik dan diterima Tuhan (Mukhlisin, Komunikasi Personal, 12 Maret 2020).

Masyarakat perdesaan Arjawinangun memandangnya sebagai hal yang alamiah, meski kebenaran agama Islam tetap diyakini sebagai hal yang absolut. Menurut mereka, naluri keberagaman yang merupakan fitrah itulah yang mendorong manusia selalu mencari sembahan sebagai Tuhan. Oleh karena itulah bermunculan berbagai sistem kepercayaan dan keyakinan dalam kehidupan manusia. Meskipun demikian, harus diyakini bahwa di antara kemajemukan agama tersebut Islam diturunkan Tuhan sebagai din atau agama yang diridhoi. Bagi mereka, Islam merupakan agama yang menyempurnakan agama sebelumnya, namun tetap diakui. Dalam hal ibadah, setiap agama tentunya berbeda-beda, namun dalam kehidupan sosial setiap umat beragama mengedepankan nilai kemanusiaan dan kebersamaan (Makruf, Komunikasi Personal, 12 Maret 2020).

Ketika dipersoalkan tentang konflik-konflik antar umat beragama di tengah Masyarakat Arjawinangun yang telah menjadikan Pancasila dan Bhineka Tunggal Ika dalam sikap dan prinsip kehidupan bermasyarakat, dalam pandangan tokoh masyarakat Arjawinangun cenderung memosisikan konflik tersebut pada ranah politis, bukan ranah ideologis. Menurutnya ada rekayasa politik yang menciptakan konflik sosial yang bernuansa SARA. Tentunya perilaku ini bertujuan menciptakan kekeruhan dalam kehidupan beragama.

Terkait dengan konflik antar agama dan intra agama peranan ulama dan pemerintah sangat penting dalam meredam konflik tersebut. Sebab patut dicurigai adanya kelompok yang sengaja merekayasa konflik, sementara pada saat yang sama masyarakat tidak memahami substansi konflik itu sendiri. Modusnya adalah membesar-besarkan perbedaan, provokasi terhadap Masyarakat, anti kemapanan, kedengkian, interes pribadi, kepentingan politis dan lain sebagainya.

Sikap pluralis yang ditampilkan oleh masyarakat perdesaan Arjawinangun ini sudah sangat jelas. Mereka memahami dengan baik bahwa pluralisme bermakna menerima perbedaan, dengan menghargai kebenaran pada orang lain dan tetap meyakini secara total kebenaran pada agama Islam sebagai agama yang dianut. Kebenaran agama lain tetap diakui sebagai kebenaran menurut pandangan dan keyakinan agama tersebut.

Masyarakat perdesaan Arjawinangun tetap menyepakati adanya konsep titik temu antara agamaagama. Menyinggung tentang pandangan kalangan pemikir liberal yang mengakui adanya kemungkinan semua agama, baik samawi maupun ardhi, menuju pada satu titik temu yang merupakan substansi utama pada semua agama, hal ini bersumber pada pernyataan Qatadah bahwa agama itu satu, sementara semangat selalu berbeda-beda: 
Ada benarnya bahwa semua agama dapat kita temukan pada satu titik temu, namun bukan pada akidahnya. Titik temunya ada pada aspek akhlak (moral). Agama-agama tidak akan disatukan pada aspek akidahnya. pada aspek akhlak pun ada pengecualian. Surah al-kafirun telah menegaskan adanya distingsi yang sangat jelas pada persoalan akidah antar agama. Agama dalam surah Ali Imron tidak dapat dipahami secara parsial dan terpotong dari kalimat sesudahnya namun sebagai titik perjumpaan dari agama sebelumnya yang diturunkan Islam hanya akan tercapai jika ada kesatuan akidah yaitu hanya menyembah Tuhan dan tidak mempersekutukannya, inilah prinsip yang harus terpenuhi untuk dapat menyatukan agama-agama." (Subhan, Komunikasi Personal, 12 Maret 2020).

Ungkapan di atas menegaskan bahwa masyarakat perdesaan tidak secara mutlak menafikan adanya kemungkinan bertemunya agama-agama pada satu substansi titik hanya salah substansi yang dimaksud adalah aspek moralitas, bukan aspek akidah yang telah mengalami distorsi yang terlampau jauh dari ketauhidan. Berkenaan dengan itu, masyarakat perdesaan menghimbau agar setiap umat tak mempersoalkan perbedaan syariat agama yang bersifat parsial. Mencari titik temu pada persoalan yang menyangkut kemanusiaan, keadilan dan kedamaian tersebut adalah kewajiban moral setiap agama.

Sikap pengakuan masyarakat perdesaan atas adanya ragam keyakinan dan agama di Arjawinangun tersebut bukan sebagai sikap pembenaran terhadap akidah orang lain atau membenarkan agama yang dipeluk oleh warga lainnya, namun hanya sebatas penghargaan atas kebebasan untuk beragama sebagaimana juga ditegaskan dalam pandangan tokoh agama forum komunikasi umat beragama yang menjelaskan bahwa:

Sistem pengetahuan dan keberagamaan komunitas masyarakat perdesaan di Arjawinangun yang pro-pluralitas keagamaan, harus ditegaskan bahwa pengakuan atau penghargaan masyarakat tersebut merupakan sikap toleransi pada asas kemajemukan keyakinan atau kepercayaan yang berkembang di tengah masyarakat merupakan penghargaan masyarakat atas hak untuk beragama baik pada rana sosial maupun ranah teologis. Pengakuan tersebut tidak beranjak dari ruang kosong, tapi secara normatif tetap berlandaskan pada substansi dan nilai wahyu Tuhan, Pluralitas merupakan realitas objektif yang nyata pada komunitas umat manusia dan pembenaran atas perbedaan tersebut kelak hanya Tuhan yang maha tahu, tugas kita adalah memahami dan menghargai perbedaan tersebut sehingga terbentuk lingkungan yang damai dan harmonis dengan sesama warga bukan hanya dalam soal agama dan kepercayaan namun dalam berbagai hal dan manusia mengambil jalan yang berbeda-beda tersebut termasuk dalam cara beragama (Firdaus, Komunikasi Personal, 16 Maret 2020).

Ideologi yang berkembang di kebanyakan masyarakat perdesaan mengakomodasi nilai pluralisme keberagamaan; pada ranah pemahaman agama di kalangan masyarakat perdesaan di Arjawinangun di atas dapat dipahami pada konsepsi berikut: Pertama, Islam mengakui, bahkan mengajak, kepada kebebasan berpikir hingga pada persoalan hukum agama sekalipun. Hal ini tentunya meniscayakan munculnya pluralitas pemahaman, pemikiran dan penafsiran terhadap teks agama dan produk hukum hasil ijtihad ulama. Sebagaimana halnya agama, perbedaan pemahaman agama tersebut adalah bagian dari realitas historis dalam sejarah dan merupakan konsekuensi dari keragaman tingkat intelektualitas manusia, situasi-kondisi yang melingkupi, dan tendensi yang memotivasinya (Gumiandari \& Nafi'a, 2020, hal. 33).

Fenomena pluralitas perbedaan pendapat atau produk ijtihad telah menjadi bagian penting dalam konteks sejarah dan peradaban Islam sehingga meniscayakan munculnya berbagai penafsiran cara beribadah yang sering kali tampak berbeda satu sama lain dari segi pemaknaan, perspektif dam hukum yang terkandung dalam ayat. Bidang fikih misalnya, muncul berbagai produk hukum fikih dan tradisi atau kebiasaan, ibadah di masa Pandemi Corona atau Covid-19, dapat ditemukan khazanah perbedaan metode, pendekatan dan cara beribadah padahal diambil dari sumber yang sama, ini mengisyaratkan bahwa hukum Islam sangat terbuka dengan keragaman pendapat, persepsi dan interpretasi.

Contoh kongkret yang sedang terjadi pada saat penelitian ini dilakukan adalah adanya pengelolaan protokol pada kegiatan ibadah dan sosial masyarakat lainnya dalam masa pandemi. Protokol Kesehatan di Kala Pandemi virus yang menyebabkan wabah penyakit menular, yang 
kemudian dinamakan dengan istilah Covid-19 (Corona Virus Disease tahun 2019). Tepatnya 11 Maret 2020, lembaga badan dunia Organisasi Kesehatan Dunia (WHO) menetapkannya sebagai Pandemi. Wabah ini menyebar ke seluruh penjuru dunia, termasuk Arjawinangun.

Kejadian luar biasa tersebut telah membuat semua kalangan masyarakat bertindak dalam menyikapi penyebaran wabah tersebut. Berbagai upaya telah dilakukan oleh masyarakat; tindakan tegas dari pihak pemerintah pun turut dijalankan (al-Asqalani, 2029). Upaya menginternalisasi kesadaran beragama dan perilaku sosial masyarakat perdesaan di Kabupaten Arjawinangun guna memberikan sikap damai antar umat beragama, pemerintah menyediakan wadah bagi umat beragama untuk menegakkan toleransi beragama yang telah lama ada dan untuk mempertahankan kebebasan di masyarakat. praktik keyakinan dan keyakinan agama.

Pemerintah melalui partisipasi seluruh pemuka agama di Arjawinangun merumuskan dan menetapkan asas kerukunan antar umat beragama. Pada masa sekarang, relatif tidak ada konflik antar pemeluk agama yang berbeda. Mungkin orang mengira menerapkan konsep harmoni itu positif. Namun ketika kerusuhan terkait agama dan tindak kekerasan terjadi di Ambon, Kupang, Poso dan daerah lainnya, konsep kerukunan antar umat beragama kembali dipertanyakan. Dapat disimpulkan bahwa keberhasilan pelaksanaan kerukunan umat beragama di Arjawinangun sampai sekarang sejalan dengan kebijakan politik penguasa saat ini, yaitu selalu menjaga stabilitas nasional demi proses kerukunan yang selalu dan setiap saat berdinamika akan lebih mudah dicegah dan dikendalikan. Pendekatan ini juga berfungsi untuk mewujudkan perdamaian antar komunitas agama dengan cara yang sama. Oleh karena itu, penting untuk mengkaji dan selalu dievaluasi kembali prinsip perdamaian antar kelompok agama yang selama ini telah diperkenalkan oleh pemerintah secara komprehensif dan menyeluruh bersama semua tokoh agama dan kepercayaan.

Internalisasi pengetahuan agama dan toleransi dalam aksi sosial masyarakat perdesaan di Arjawinangun tercermin dalam aktualisasi sikap toleransi sosial yang terkonsentrasi di kalangan umat beragama; Keamanan setiap pemeluk agama adalah bukan tanggung jawab penganut agama itu sendiri namun menjadi tanggung jawab bersama dan ketika mereka memiliki cara ibadah dengan sistem dan metode sendiri hal tersebut hanya berlaku dan dikenakan pada kelompoknya mereka sendiri (Subaweh, Sumiyadi, Iskandarwassid, \& Permadi, 2020, hal. 225).

Agama bagi masyarakat Arjawinangun adalah hak dan keyakinan dari masing-masing individu dan itu tidak bisa diganggu gugat oleh siapa pun, masyarakat berhak memilih keyakinan dan melaksanakan keyakinan agamanya tersebut dengan tenang dan damai menjadi cerminan dari sikap religius pemeluk agama dalam kehidupan sosial masyarakat di antara individu yang seiman, lain iman dan kepercayaan, namun dalam masalah sosial dan kehidupan selain masalah agama mereka guyub dan rukun saling bergotong royong tanpa membedakan apa agamanya.

\section{Teologi Keagamaan Masyarakat Perdesaan}

Kerukunan ini diketahui terjadi bahwa akibat adanya mekanisme alam yang sudah terbentuk lama di Arjawinangun sehingga mengakibatkan persoalan-persoalan yang sangat kompleks namun dapat diselesaikan dengan baik oleh masyarakatnya itu sendiri, sehingga tidak menyebabkan terjadinya bencana sosial. Dampak yang muncul begitu rupa turut mendukung teori sebelumnya yang dikemukakan kalangan sosiolog yang menjelaskan bahwa kehidupan masyarakat tidak akan berjalan statis tetapi akan selalu berubah; dinamis mengikuti kondisi pada zamannya. Menurut More, perubahan sosial bisa diartikan sebagai suatu perubahan pada berbagai aspek penting dalam bentuk perilaku, struktur sosial, atau sistem sosial, termasuk di antaranya adalah norma, nilai, budaya dan fenomena kultural masyarakat lainnya (Narwoko \& Suyanto, 2007, hal. 362).

Perubahan akan selalu hadir dalam setiap perjalanan hidup umat manusia; hadir sebagai dinamika dalam mewarnai kehidupannya. Demikian pula yang terjadi dengan masyarakat perdesaan di Arjawinangun cenderung mengidentikkan dirinya sebagai masyarakat yang hidup lengkap dengan ciri-ciri dan karakteristik kehidupan yang bervariatif (Narwoko \& Suyanto, 2007; Soekamto, 2003, hal. 155). Menurut teori adaptif, masyarakat perdesaan di Arjawinangun cenderung mengalami dinamika hidup bermasyarakat yang kompleks, karenanya mereka senantiasa berusaha untuk mengadaptasikan 
diri dengan lingkungan komunitasnya; berusaha beradaptasi untuk menyesuaikan diri. Pola hidup adaptif tersebut merupakan pendekatan yang paling tepat untuk mencapai tujuan atau kepentingan; untuk dapat bertahan hidup, saling menghormati, dan saling melengkapi untuk mempertahankan hidup berdampingan dengan masyarakat lainnya (Soekamto, 2003).

Kalangan masyarakat perdesaan di Kecamatan Arjawinangun juga mengidentikkan dirinya sebagai masyarakat nomaden, karena sesuai dengan profesinya sebagai pedagang mereka selalu berputar dari pasar ke pasar yang lainnya, hal ini dipandang berbeda dengan kalangan masyarakat lainnya. Perbedaan antara masyarakat Arjawinangun dengan masyarakat lainnya menurut mereka lebih bersifat elastis, meskipun sulit untuk memberikan batasan definisi yang jelas apa yang dimaksud dengan perilaku nomaden masyarakat Arjawinangun karena terjadi disebabkan oleh adanya hubungan dagang antara masyarakat yang menetap dengan masyarakat yang sengaja berdagang dengan indikator sosial yang dinamakan mobilitas tinggi dari aktivitas berdagang antar daerah (Koentjaraningrat, 2005, hal. 136).

Pendapat di atas sejalan dengan teori urbanisasi yang dikemukakan oleh Adi Setijowati yang menjelaskan bahwa warga masyarakat seperti di Arjawinangun tergolong masyarakat multi etnis karena terdiri dari berbagai suku, bahkan dalam wilayah tertentu; mereka memiliki budaya yang beragam; latar budaya yang berbeda tergantung dari mana mereka berasal (Setijowati, 2010, hal. 94).

Seperti telah dijelaskan peneliti pada bab sebelumnya, pembentukan sifat dan kesadaran keagamaan setiap manusia dibentuk melalui dua faktor, yaitu faktor pembawaan dan lingkungan. Tanpa menyebutkan identitas agama yang dianut oleh setiap orang, peneliti berpendapat bahwa kedua faktor inilah yang dipandang sangat mempengaruhi masyarakat perdesaan untuk berinteraksi dengan entitas masyarakat lainnya yang lebih dulu lahir dan telah lama tinggal dan mengenalkan budaya luar dari tempat asal ke masyarakat yang berbeda agama maupun keyakinan itu sendiri.

Proses terjadinya kesadaran dalam beragama dan sikap toleransi menjadi tabiat sosial masyarakat perdesaan dapat dimulai dari preposisi bahwa setiap personal yang lahir memiliki hereditas tertentu. Karakteristik individu juga didapatkan melalui pewarisan atau doktrin dari mana asal masyarakat perdesaan itu datang, dari keluarga seperti apa, bagaimana tradisi keagamaannya, dan bagaimana pula cara mereka mengaktualisasikan kesadaran beragama dalam perilaku sosial.

Kesadaran beragama masyarakat ini tidak lepas dari pengaruh lingkungannya, oleh karenanya secara sederhana pertanyaan-pertanyaan di atas barulah terjawab dengan cara merumuskan hipotesis sementara bahwa di antara faktor yang paling dominan dalam pengaruh kesadaran beragama ataupun kepribadian pada masyarakat berasal dari faktor pembawaan dan faktor lingkungan.

Kelebihan manusia adalah dianugerahi fitrah untuk mengenal Tuhan dan menerima ajarannya; Setiap manusia lahir dengan naluri religius atau naluri supernatural, yang berarti mereka disebut sebagai "homo deviants". Sifat religius ini merupakan tawaran yang memberikan peluang bagi perkembangan jalan beragama manusia yang sesuai dengan arah dan kualitasnya.. Proses tersebut sangat tergantung pada proses pencarian yang diterimanya, dan hal tersebut akan memberikan gambaran cara beragamanya bahwa ada faktor lain yang membentuk kesadaran beragama untuk manusia selain faktor bawaannya.

Masyarakat Arjawinangun yang beragam dalam segi apa pun mampu menonjolkan toleransi yang terbukti ampuh dalam menunjang perdamaian. Tentu hal ini seharusnya dapat dijadikan contoh bagi daerah lainnya agar menjadikan kehidupan lebih damai tanpa adanya konflik yang berujung pada konflik sampai pada peperangan. Untuk menuju perdamaian tersebut, masyarakat perdesaan Arjawinangun memiliki sebuah kunci agar dapat selalu dalam kedamaian. Bagi mereka, sikap toleransi merupakan kunci untuk menuju perdamaian itu sendiri.

Masyarakat perdesaan Arjawinangun mengambil pelajaran berharga atas munculnya konflik di beberapa bagian wilayah yang disinyalir karena nilai toleransi itu sendiri telah hilang diantara setiap individu dan kelompoknya. Di dalam bertoleransi diharapkan setiap masyarakatnya mampu menghargai dan menghormati sesama yang pasti memiliki perbedaan dengan yang lainnnya untuk dapat mewujudkan hal ini bukan berarti tanpa masalah setiap individunya yang berbeda terkadang berpendapat keras dalam artian sulit untuk diatur hanya dengan sebuah toleransi yang ada. Ketika 
toleransi yang sifatnya luwes dan fleksibel tidak mampu diterapkan dimasyarakat, maka hukum adalah hal yang diterapkan selanjutnya.

Kalangan masyarakat perdesaan Arjawinangun beranggapan bahwa terciptanya peraturan antara lain untuk mengatur kehidupan masyarakatnya agar dapat terciptanya suasana yang kondusif dalam bermasyarakat, akan tetapi apabila masyarakat mampu bertoleransi maka hukum tidak perlu ditegakkan secara ketat karena hadirnya toleransi sendiri sebenarnya dapat mengatur kehidupan yang harmoni dalam bermasyarakat. Toleransi dan hukum sebenarnya memiliki peran yang sama akan tetapi dampak dan akibat yang ditimbulkannya berbeda.

Masyarakat perdesaan Arjawinangun juga memiliki asumsi bahwa apabila seseorang melanggar hukum yang berlaku maka dilakukan tindakan pembuat jera antara lain berupa denda dan hukuman bahkan penjara. Namun apabila seseorang melanggar norma-norma toleransi maka orang tersebut hanya akan mendapatkan hukuman dari orang-orang sekitar yang dapat berupa diacuhkan atau bahkan dijauhi. Sifat toleransi yang fleksibel mampu diikuti dengan mudah oleh wilayah-wilayah lain akan tetapi penerapannya sendiri sebenarnya cukup sederhana yaitu dengan kesadaran setiap individunya masing-masing lalu secara mengalir berpindah ke kelompok dan akhirnya pada masyarakat itu sendiri dan berdampak kedamaian sebuah wilayah.

Kondisi Arjawinangun yang beragam, membuat bangga masyarakat, dengan keadaan masyarakat beragama dapat mendorong yang lain menerapkan toleransi dalam bermasyarakat. Diplomasi untuk terus mendukung dan mendorong toleransi akan berbuah pandangan baik dari wilayah lainnya sehingga ikut serta membangun stabilitas wilayahnya sendiri. Sebagai wilayah yang penuh toleransi dengan jumlah perbedaan terbesar di Cirebon masyarakat mampu menerapkan toleransi yang berujung perdamaian di setiap daerahnya, walaupun pada kenyataannya masih ada saja percikanpercikan kecil di dalam menjalankan praktik keagamaan menuju perdamaian ini. Pemerintah sebagai pengatur sebuah wilayah diharapkan dapat mendorong seadil-adilnya khususnya pada sikap warga agar kedamaian yang berbuah dari toleransi mampu terus berjalan tanpa adanya hambatan berarti.

Apabila dikaji dari perspektif filsafat agama, awal mula terbentuknya kesadaran sikap beragama dan toleransi di kalangan masyarakat perdesaan Arjawinangun adalah karena adanya aspek religiusitas tokoh agama dan masyarakatnya, hal ini berkaitan erat pada aspek keimanan dan aktualisasi ajaran agama dalam kehidupan sehari-hari melalui peribadatan kepada-Nya, baik hubungan antar manusia dengan Tuhan maupun manusia dengan manusia. Realisasi iman dan internalisasi ibadah menjadi motivasi masyarakat yaitu munculnya kesadaran pada diri sendiri terhadap nilai-nilai yang ada dalam ajaran agamanya.

Hasil penelitian di lapangan menemukan bahwa di antara faktor internal yang mempengaruhi terbentuknya sikap kesadaran dalam beragama dan toleransi di warga masyarakat perdesaan Arjawinangun dapat dilihat dari pemahaman mereka terhadap masalah-masalah pokok dasar agama. Misalnya saja, masih ada pemahaman bahwa manusia memiliki fitrah untuk beragama, yang berbeda dengan hewan, yang bisa hidup semaunya sendiri tanpa aturan agama.

Pendapat tersebut mendukung teori kesadaran beragama yang dikemukakan oleh Glock dan Stark dalam kajian Roland Robertson yang menjelaskan bahwa ada lima dimensi yang dapat dibedakan dalam sikap keagamaan; namun semua konsep ilahi yang banyak dan beragam dari agama-agama dunia yang berbeda dapat dikategorikan dalam kesehariannya menjadi ciri khas dari mereka. Dimensi ini akan kita sebut sebagai bentuk aktualisasi dari keyakinan, praktik, pengalaman, ritual, dan pengetahuan. Proses pembentukan sikap kesadaran beragama tersebut pada akhirnya akan membentuk dimensi keyakinan, peribadatan atau praktik agama, pengalaman, pengamalan dan pengetahuan agama (Robertson, 1969, hal. 256).

Hasil analisis peneliti melihat adanya perkembangan kesadaran dalam sikap beragama ini Apabila dianalisis dari teori studi agama, Joachim Wach menjelaskan bahwa pembentukan kesadaran beragama di kalangan masyarakat perdesaan terbentuk karena ketiga hal yaitu: afektif, kognitif dan motorik (Wach, 1984, hal. 185). Faktor tersebut berjalan secara alamiah disebabkan sejak kecil mereka sudah memperoleh didikan agama, sehingga fitrah nalurinya berkembang ke hal-hal yang positif sesuai dengan apa yang diajarkan oleh agama yang dianutnya. Keyakinan beragama merujuk kepada 
firman Tuhan dalam al-Qur' an surat al- A'raf 7:172: surat ar-Ruum 30:30 dan surat asy-Syam 91:8. Ayat tersebut menyiratkan adanya fitrah alamiah dasar setiap manusia.

\section{Peran Tokoh Agama}

Terbentuknya kesadaran sikap beragama dan toleransi di kalangan warga masyarakat perdesaan di Arjawinangun secara eksternal juga dipengaruhi adanya fitrah, fitrah beragama adalah potensi setiap manusia yang mempunyai kecenderungan untuk berbuat baik. Potensi ini akan muncul apabila ada faktor luar yang memberikan stimulus positif baik berupa bimbingan, pengajaran atau pendidikan yang menjadikan fitrah alamiah tersebut berkembang.

Mengutip pendapat beberapa ahli dalam bukunya Jalaluddin Rakhmat, kesadaran afektif beragama terbentuk karena: Pertama pandangan dari Fredric Hegel, agama benar-benar ilmu dan menjadi tempat kebenaran yang kekal, dan akibatnya sentimen manusia sangat kuat untuk mengetahui dan bergabung di dalamnya. Kedua, Gagasan Fredrick Schleimacher, adanya rasa ketergantungan total terhadap agama. Dengan ketergantungan total ini, orang merasa rentan, kerentanan inilah yang menyebabkan orang mengandalkan hidup mereka dengan kekuatan luar. Konsep ketergantungan agama ini memunculkan konsep tentang Tuhan, atas dasar rasa ketergantungan ini.

Manusia selalu tidak berdaya dalam menghadapi tantangan eksistensi, dan mereka mengandalkan kekuatan absolut. Keyakinan pada Tuhan untuk melindunginya berasal dari ide ini makhluk berharap untuk bisa memperoleh perlindungan-Nya. Ketiga, akar dari psikologi agama, menurut W.H. Thomas, adalah keinginan umum manusia: keinginan untuk dilindungi, untuk mendapatkan pengakuan, untuk menjadi perhatian dan berharap untuk pemahaman dan pengalaman baru. Tujuan tersebut dapat tercapai apabila mereka melakukan perintah dan menjauhi semua apa yang dilarang secara ikhlas atas pengabdian kepada Tuhan agar tercipta rasa damai melalui doktrin agama sehari-hari (Rakhmat, 2003, hal. 54).

Pengetahuan agama dibangun dari keinginan akan kebutuhan spiritual manusia sehingga manusia tidak dapat membedakan dirinya dari apa yang mereka sebut agama. Ketika masyarakat menemukan dan mengikuti agama tersebut dengan perasaan ikhlas ingin mengabdikan diri kepada Tuhan, jiwa mereka akan merasa tenang dan rileks. Pada aspek kognitif menjadi aspek yang melalui proses berpikir menjadikan seseorang sebagai sumber agama bagi agama. Sedangkan kehidupan beragama merupakan representasi dari potensi pemikiran manusia, karena agama sendirilah yang menjadi alasannya.. Sementara itu, kehidupan beragama mewakili kemampuan berpikir manusia dengan mengandalkan fakta atau realitas untuk percaya pada keyakinan agama, masyarakat juga menggunakannya dengan olah pikiran mereka pada dimensi abstrak dari kesadaran beragama yaitu:

Pertama, adanya hikmah yang menginspirasi hati untuk menjalin hubungan spiritual dan relasi ibadahnya dengan Tuhan, yaitu akal budi yang memungkinkan hati mengetahui hati dan tindakannya, mengendalikan dan mengartikulasikan hati dengan benar. Persepsi ini terkait dengan pengakuan logis ketuhanan dan pembenaran untuk menekankan nilai-nilai teosentris yang fundamental daripada nilai antroposentris yang bersifat sementara. Pengetahuan ini juga dapat dilihat dari keyakinan seseorang pada dasar-dasar agama dan cara ibadah kepada Tuhan. Kedua, memiliki kecerdasan emosional adalah kecerdasan yang terkait dengan regulasi impulsif dan kekerasan dari keinginan yang bertujuan untuk berperilaku bijaksana, waspada, tenang, berhati-hati, stabil dalam krisis, dan bahagia saat Anda menikmatinya. Ketiga, kecerdasan moral tentang manusia dan alam semesta. Kesadaran ini menuntun kita untuk berbuat baik setiap saat.

Keempat, mempunyai kecerdasan spiritual terkait dengan konsistensi batin seseorang. Akal ini menuntun seseorang mengenal Tuhannya, sehingga melalui penggunaan akal budi seseorang dapat mencapai cita-cita mulia sesuai petunjuk agama. Kecerdasan spiritual juga berhubungan dengan kualitas spiritual seseorang dalam menjalankan ajaran agamanya. Kelima, meningkatnya cara beragama berkaitan dengan kualitas beragama dan konsistensi iman sendiri, atau pengetahuan teologis. Akal ini akan menuntun seseorang untuk berperilaku religius yang mengarah pada pengabdian dan keyakinan yang dalam sehingga berdampak pada sikap ketakwaan dan keimanan seseorang dengan benar (Ramayulis, 2002, hal. 79). 
Pembentukan sikap atau pengalaman cara beragama ini jika dilihat dari aspek kognitif maka kesadaran dalam beragama seseorang mengarah pada keyakinan terhadap nilai-nilai yang diajarkan agama, dengan cara berpikirnya tersebut masyarakat dapat menentukan sendiri mana diantara hal yang benar dan tidak benar, secara kognitif masyarakat mampu secara bertahap mulai menginternalisasikan keyakinan atau keimanan tersebut sebagai ungkapan atas pengalaman rohaninya yang memperoleh ketenteraman jiwa.

Kesadaran beragama juga diaplikasikan dalam pelbagai aktivitas dan ritual keagamaan, sepeti: disiplin beribadah, menunaikan ibadah puasa, berakhlak baik, dan saling menghormati sesama. Sifat motorik dalam kesadaran beragama, juga mendorong setiap orang senantiasa menjaga dirinya agar tetap melakukan hal yang baik dan berusaha keras untuk terhindar dari semua perbuatan yang tercela dan dilarang oleh ajaran agama. Terbentuknya sikap dan kesadaran dalam beragama dan toleransi di kalangan masyarakat perdesaan dipengaruhi oleh faktor lingkungan di keluarganya. Walter Houston Clark berpandangan bahwa, pertumbuhan seorang anak biasanya tidak akan terjadi tanpa rangsangan dari luar, meskipun hal itu tentu saja sudah bersifat bawaan. Dalam tumbuh kembangnya, ketika seorang anak hanya diperlakukan sebagai manusia normal, maka ia juga membutuhkan perlakuan dan perlakuan yang terus menerus tersebut (Clark, 1964, hal. 2).

Psikolog Hurlock menyatakan bahwa keluarga menjadi pusat pelatihan penanaman keyakinan agama dan nilai-nilai dari ajaran agama itu sendiri. Gagasan ini menegaskan adanya peran keluarga sebagai awal pendidikan bagi anak-anak dalam mengenali tata nilai atau pendidikan agama dan kemampuan mereka untuk mengamalkan atau memasukkan nilai-nilai tersebut secara individu ataupun dalam komunitas kehidupan masyarakat sehingga memiliki peran yang sangat dominan dibandingkan dengan peran lainnya (Hurlock, 1980, hal. 167).

Peran keluarga ini sangat erat kaitannya dengan cara orang tua dalam menanamkan agama pada anak-anaknya, upaya orang tua sebelum kelahiran anak diantaranya membaca doa saat berada dalam hubungan suami istri; meningkatkan ibadah; berdoa; tadarus al-Qur'an; berdoa untuk memperoleh anugerah anak-anak yang saleh, memperbanyak sedekah; dan mencegah melakukan sesuatu ucapan atau perbuatan yang dilarang dalam agama sedangkan setelah anak lahir diantaranya melaksanakan aqiqah; mendidik anak tentang ajaran agama; memelihara hubungan yang harmonis antar anggota keluarga; mengajarkan akhlak karimah; dan memperlakukan anak dengan cara yang baik; tidak memperlakukan anak secara otoriter.

Berdasarkan riset ahli psikolog bahwa penderita gangguan jiwa secara umum sangat dipengaruhi oleh keadaan emosional ibunya pada saat masih janin sesuai dengan perkembangan dalam rahimnya. Upaya orang tua untuk menumbuhkan jiwa religius anaknya di dalam kandungan secara implisit dilakukan karena praktik tersebut cenderung meningkatkan keyakinan agama, adat istiadat dan perilaku orang tua (Putri, Wibhawa, \& Gutama, 2015).

Selain hal di atas, orang tua yang memiliki sisi keagamaan lebih memilih untuk mendaftarkan anaknya di pesantren begitu juga dengan orang tua yang merasa kesulitan untuk memantau tindakan anaknya memilih memasukkannya ke pesantren dengan harapan akan berdampak pada perkembangan anaknya. Pendidikan agama di pesantren akan memberikan pengaruh bagi kesadaran beragama dan sikap toleransi di kalangan generasi masyarakat perdesaan Arjawinangun. Namun besar kecilnya pengaruh sangat dipengaruhi oleh beragam faktor. Hal tersebut dikarenakan pendidikan agama pada hakikatnya bukan penentu tapi hanya sebatas lembaga pendidikan yang memberikan pelajaran etika dan nilai sehingga faktor ini tampaknya lebih disebabkan pada bagaimana membentuk kebiasaan yang baik sejak dini dan selaras dengan etika dan moral dalam agama.

Selanjutnya lingkungan masyarakat juga memiliki andil dalam membentuk lingkungan atau struktur sosial dan sosial budaya yang berpotensi mempengaruhi identitas keagamaan anak dan remaja kemudian kebudayaan. Dalam budaya, setiap orang harus belajar untuk berkomunikasi menggunakan empati karena ruang sosial masyarakatnya berbeda. Demikian pula dengan teman dalam bergaul, mereka sudah diajarkan untuk berperilaku yang sesuai dengan nilai-nilai agama sehingga masyarakat yang berbeda agama maupun keyakinan akan cenderung menyesuaikan diri dengan perilaku masyarakat perdesaan di Arjawinangun. Namun apabila sebaliknya, yaitu perilaku 
masyarakat perdesaan di Arjawinangun dalam sepergaulannya itu menunjukkan kebobrokan moral, maka masyarakat yang berbeda agama maupun keyakinan akan cenderung terpengaruh untuk berperilaku seperti masyarakat perdesaan di Arjawinangun tersebut. Hal ini terjadi, apabila masyarakat yang berbeda agama maupun keyakinan tidak mendapatkan kesempatan untuk bersosialisasi dan beradaptasi dengan kondisi sosial masyarakat Arjawinangun.

Mengenai dominannya hubungan saling mempengaruhi antara masyarakat perdesaan di Arjawinangun dengan masyarakat yang berbeda agama maupun keyakinan, tokoh masyarakat menyatakan bahwa prinsip atau hukum tidak tertulis sangat mempengaruhi pandangan moral dan perilaku orang secara kolektif. Pola perilaku sosial masyarakat perdesaan juga dipengaruhi oleh perilaku sosial masyarakat pada umumnya misalnya pemahaman agama dan penerimaan perilaku sosial sangat tergantung pada standar perilaku anggota kelompok masing-masing.

Peningkatan kualitas diri, pengembangan kepribadian, dan implikasinya terhadap perilaku sosial di kalangan masyarakat perdesaan pada gilirannya sangat erat kaitannya dengan tingkat kesadaran beragama, di mana masyarakat yang taat melaksanakan ajaran agamanya mampu memberikan pengaruh positif bagi perkembangan kejiwaan sendiri dan masyarakat sekitarnya. Hubungan antara kondisi lingkungan dan sikap toleransi dalam perilaku sosial masyarakat perdesaan terhadap internalisasi agama di lingkungan masyarakat religius perdesaan memberikan pengaruh positif dalam jiwa dan karakter kesehariannya dibandingkan dengan masyarakat yang tidak memiliki ikatan sosial atas dasar norma keagamaan.

Motif budaya dagang sangat erat kaitannya dengan faktor yang mempengaruhi aktivitas kolektif masyarakat Arjawinangun; menjadi faktor kunci terciptanya harmoni. Pembangunan ekonomi berbanding lurus dengan keadaan masyarakat yang toleran secara budaya bahkan orang dari agama dan budaya lain, khususnya orang Tionghoa, memiliki kepemilikan unit usaha yang sangat dominan di bidang ekonomi. Ada ungkapan bahwa dimana ada warga Tionghoa maka daerah tersebut akan maju pesat dengan aktivitas perdagangannya dibandingkan dengan daerah yang tidak dihuni oleh warga Tionghoa akan berjalan sangat lambat khususnya dalam bidang ekonomi.

Hal ini menunjukkan bahwa meski berbeda keyakinan, mereka memberikan kontribusi yang signifikan terhadap kegiatan ekonomi di Arjawinangun. Industri jasa dengan daya saing yang tinggi dan komposisi yang sangat heterogen terbuka lebar untuk diperdagangkan. Meski berbeda agama, mereka mengklaim bahwa bagi banyak orang, keberadaan warga negara China bisa membawa keberuntungan tersendiri. Arjawinangun sangat terbuka untuk mereka, seperti yang kita ketahui, terjaganya suasana kerukunan telah membuat masyarakat Tionghoa merasa nyaman khususnya di bidang ekonomi untuk saling beradaptasi dengan masyarakat yang berbeda agama dan kepercayaan dalam interaksi sosial.

Kehadiran masyarakat Tionghoa memberikan kontribusi lebih bagi perekonomian Arjawinangun, seperti yang sudah dijelaskan. Masyarakat sangat terbantu karena mereka memberikan pekerjaan kepada kelompok lain untuk membuat orang percaya bahwa mereka mendapat untung dari kegiatan ekonomi mereka, meskipun berbeda agama mereka tetap rukun dan tepo seliro. Selain terlibat dalam bidang sosial dan ekonomi, peneliti sering mencatat bahwa terdapat berbagai perbedaan tingkat keimanan dan pengalaman ilmu agama yang berbeda antar individu, namun mereka memiliki kesadaran yang sulit untuk diukur secara obyektif sehingga kehidupan beragama hanya dapat ditemukan. dalam perilaku yang muncul sebagai pernyataan seseorang dalam kehidupan sehari-hari.

Rasa beragama, pengalaman akan ketuhanan, iman, sikap dan agama di kalangan masyarakat perdesaan di Arjawinangun termasuk tingkah laku. Struktur mental dan sikap dalam mengoordinasikan agama. Pemahaman religius mencakup unsur produktif, konatif, kognitif dan motorik karena menyangkut seluruh fungsi tubuh dan jiwa manusia. Peran yang efektif dan konduktif pada bagian dari praktik keagamaan dan pengabdian masyarakat pada Tuhan, seperti dalam keyakinan, aspek kognitif yang muncul. Dalam tindakan dan gerak aktivitas keagamaan, fungsi iman terlibat. Banyak unsur yang sangat sulit diduga dalam kehidupan sehari-hari di masyarakat karena dalam kepribadian seseorang secara utuh merupakan suatu struktur cerminan dari aktualisasi pengetahuan agama yang dianutnya. 
Tidak ada perbedaan dari persyaratan identitas seseorang ketika mereka mampu mendefinisikan konsistensi kesadaran beragama karena kesadaran kompleks ini hanya dapat ditemukan pada mereka yang telah memiliki pribadi yang matang meskipun pribadi yang dewasa tidak menjamin memiliki pemahaman agama yang kuat karena ada seseorang yang tidak beragama meskipun tidak sadar akan agama tapi ia memiliki kepribadian yang matang. Namun fakta di lapangan terlihat bahwa kesadaran beragama yang kokoh berada pada kepribadian yang belum dewasa sulit dijelaskan, karena bagaimana pun juga konsistensi keilmuan agama itu kompleks, berwarna-warni dan sesuai dengan kepribadian seseorang.

Peneliti mendukung pendapat bahwa pengetahuan dan toleransi beragama memiliki tiga ciri kepribadian yang matang: pertama, perkembangan psikologi sosial, orientasi keyakinan dan minat, yang berkontribusi pada idealisme dan nilai-nilai sosial budaya yang secara biologis tidak diperlukan. Seseorang yang sudah dewasa harus bisa mengatur naluri dan keinginan biologisnya sehingga kepuasannya sesuai dengan norma sosial budaya masyarakat. Di sisi lain, orang-orang tanpa dorongan biologis atau tindakan yang dikendalikan oleh nafsu menunjukkan kepribadian mereka seperti masa kanak-kanak karena karakter dewasa tidak lagi egois.

Ketiga, memiliki fokus pada diri sendiri, untuk melihat diri secara kritis dan untuk mempertimbangkan keberadaannya sendiri. Kemampuan untuk membedakan diri dan melihat diri sendiri sebagai entitas sedemikian rupa sehingga mereka dapat membandingkan hal-hal tentang dirinya, belajar memahami diri sendiri. Ketiga, ideologi lengkap dari kepribadian yang dewasa sering kali muncul dari filosofi agama atau diekspresikan secara tidak tepat. Kehidupan seseorang dapat terlihat terpisah-pisah, tersegmentasi, dan tidak berguna tanpa adanya konsep dan tujuan hidup yang digerakkan oleh agama sehingga gaya hidupnya tidak terintegrasi atau menjadi tidak teratur.

Orang tua yang berasal dari masyarakat perdesaan Arjawinangun, yang terlihat memiliki pengetahuan agama mewariskan norma-norma agama pada anak-anak, bertanggung jawab atas warisan nilai-nilai dan tradisi agama. Anak-anak mereka tidak selalu religius saat lahir, namun hanya memiliki kemampuan atau kecenderungan untuk menjadi orang yang religius. Pengetahuan agama bagi anak belum tumbuh optimal, namun ada kapasitas psikologis dan landasan hidup beragama yang sudah dihafal. Agama, sikap, dan perilaku religius orang tua sangat mempengaruhi psikologi anak, warna kepribadian anak dan pola interaksi kepekaan beragama anak mereka. Kondisi emosional orang tua berdampak pada perkembangan mental anak sejak menjadi janin yang berada di dalam kandungan.

Pengetahuan agama menunjukkan adanya makna dan konsistensi sesuai dengan kepribadian seseorang. Setiap proses perkembangannya menunjukkan adanya ciri-ciri umum. ilmu agama di kalangan anak-anak perdesaan sangat ditekankan sejak kecil, sedangkan tumbuhnya kesadaran beragama terus berlanjut sesuai dengan pengalaman religius masing-masing yang lebih efektif, emosional, dan lepas dari sifat ego. Anak memperoleh pengalaman spiritual melalui hubungan emosional otomatis dengan orang tua, hubungan emosional yang dipahami sebagai cinta dan keakraban antara orang tua dan anak, yaitu melalui siklus kekaguman dan peniruan yang belum sepenuhnya dipahami anak mengenai sikap dan perilaku orang tua. Secara psikologis fase dewasa ditandai dengan kematangan mental, pemahaman akan kebenaran, penerimaan terhadap pandangan yang berbeda dari orang lain dan optimisme terhadap kehidupan. Sementara dari sisi pedagogis, memiliki tanggung jawab atas perbuatannya dan memiliki kepedulian untuk menjaga kesehatan diri sendiri dan orang lain; itu sejalan dengan prinsip dan nilai moral agama (Fossas, 2019).

Perkembangan keberagamaan seseorang terlihat dalam bentuk ibadah yang tulus, kondisi kejiwaan lebih stabil. Sikap beragama masyarakat perdesaan di Arjawinangun lebih rileks terhadap konten agama, stabilitas agama ini tidak hanya didasarkan pada pertimbangan logika tetapi juga pada hati nurani, dan kekuatan kepribadian dalam merangkul, menumbuhkan dan menegakkan ajaran agama yang dianutnya; sejauh mana ketaatan beragama ditentukan oleh ketaatannya dalam melaksanakan kewajiban sebagai perwujudan sikap hidup.

Kesadaran beragama dan sikap toleransi pada orang dewasa di perdesaan lebih matang secara rohaniah. Hal ini terjawab dengan keimanan yang direfleksikan ke dalam berbagai perilaku dan ritual 
keagamaan. Demikian pula dengan sifat kritis terhadap ajaran agama semakin terfragmentasikan dalam perilaku dan perbuatan. Selain bidang agama masyarakat perdesaan di Arjawinangun sudah mapan dalam menghadapi perbedaan keagamaan yang bercampur dengan budaya dan norma-norma kehidupan lainnya. Agama-agama dengan kepercayaan yang lebih tradisional lebih menonjol dalam menjaga ajaran agama mereka sejalan. Pada akhirnya yang tumbuh adalah kesadaran beragama dan sikap toleransi yang bertipe inklusif. Seperti telah dijelaskan sebelumnya sikap inklusif ini mengacu pada tingkah laku dan pandangan religius seseorang bahwa selalu ada realitas di luar agama, meskipun tidak seutuhnya atau sesempurna agama yang dianutnya. Penerimaan dan keyakinan teologis terus ada, namun demikian, pola pikir egaliter sering menemukan agama lain melekat dalam komitmen pada keyakinan agamanya.

Ide di atas untuk menafsirkan kepercayaan orang lain dengan mata kepala mereka sendiri dan untuk menekankan nilai-nilai kebajikan dan kehormatan lainnya dalam sifat positif dari iman dan penerimaan dalam masyarakat. Tanpa mengkritik orang lain, setiap orang harus dengan bebas mengikuti jalan mereka sendiri. Selain itu, pelaksanaan peribadatannya dapat bersifat praktis dan universal. Sikap inklusif sering kali menghadapi tekanan sehingga memunculkan sikap arogan. Bahwa dia sendiri yang memiliki kesempatan untuk memperoleh surga dan keselamatan yang mencakup semua, termasuk posisi paling penting di dunia untuk orang lain.

Masyarakat perdesaan merupakan entitas sosial non origin dari penduduk di Arjawinangun, mereka juga sangat terbuka untuk mengakui adanya pluralis. Sikap teologis pluralis ini dapat disajikan sebagai cara yang sama benarnya untuk mendialogkan kebenaran agama yang sama, dari berbagai aspek kajian. Pluralis juga berbicara agama dari sudut yang berbeda, tetapi mereka tetap memiliki kebenaran sejati yang sama, atau sebagian besar kebenaran disampaikan oleh agama tersebut.

Sebagai inti sari dari hasil temuan penelitian keagamaan masyarakat ini, peneliti merumuskan bahwa analisis teori studi agama berkorelasi dengan berbagai dimensi kesadaran beragama yang mana di dalamnya adalah sikap toleransi, dan perilaku atau norma sosial di kalangan masyarakat perdesaan yaitu relasi kesadaran dalam beragama, sikap toleransi, dan perilaku sosial di kalangan masyarakat perdesaan Arjawinangun dapat digambarkan sebagai berikut:

Pengamalan aktivitas nyata menjelaskan ajaran agama dalam kehidupan sehari-hari; kesadaran hidup pada masyarakat perdesaan yang diorientasikan untuk kembali kepada Tuhan pengetahuan. Pemahaman tentang konsep keyakinan sistem ketuhanan, sistem norma dan nilai, mekanisme peribadatan, dan cara menghayati ajaran agama adanya pemahaman tentang keyakinan sistem ketuhanan, sistem norma dan nilai, mekanisme dalam hal peribadatan, dan cara menghayati ajaran agama seutuhnya ini cenderung memiliki kesamaan dengan kesadaran beragama dari konsepnya Roland Robertson dan Joachim Wach (Robertson, 1992; Wach, 1984).

Pada aspek ibadah saling menghormati persamaan dan perbedaan dalam cara beribadah tumbuhnya kesadaran untuk saling menghormati persamaan dan perbedaan dalam menjalankan ibadah muammalah saling berinteraksi antara sesama muslim dan non muslim tumbuhnya kesadaran untuk saling berinteraksi antar sesama muslim dan non muslim sesuai dengan konsep dari sikap toleransi Abdurrahman Wahid, Abdullah Ali dan Umar Hasyim (Ali, 2007; Hasyim, 1979; Wahid \& Ikeda, 2010).

Perilaku Sosial masyarakat Arjawinangun sejalan dengan gagasan dari George Ritzer, Douglas J. Goodman dan Max Weber yaitu tujuan dan tindakan ditentukan oleh motivasi terhadap perilaku obyek baik dalam lingkungan dan juga komunitas lain. Tindakan merupakan respons terhadap obyek dan keinginan subyek lain dalam lingkungan sosial nilai tindakan yang muncul dan ditentukan realitas keyakinan kesadaran akan nilai perilaku-perilaku etis, estetis, religius atau bentuk perilaku lain, yang terlepas dari prospek keberhasilannya (Ritzer \& Goodman, 2017; Weber, 2009). Tumbuhnya keyakinan kesadaran beragama akan memunculkan nilai etika, estetika, perilaku religius atau bentuk tindakan lain yang muncul dan ditentukan oleh kondisi emosional aktor terlepas dari adanya prospek dari orang lain (Ihsan, 2009).

Berdasarkan uraian di atas, pembahasan dan analisis penelitian keagamaan masyarakat Arjawinangun ini, peneliti dapat merumuskan bahwa sikap kesadaran beragama masyarakat di 
kecamatan Arjawinangun merupakan bentuk pengembangan perilaku sosial masyarakat perdesaan khususnya perubahan pola pikir dan perilaku keagamaan dan sikap toleransi mereka yang dipengaruhi oleh sikap dan keteladanan dari tokoh agama. Sebagai tesis, ketika masyarakat perdesaan berinteraksi pada asalnya masih memiliki pemahaman dan kesadaran beragama yang eksklusif sebagai barang bawaan dari keyakinan awalnya. Kemudian sebagai antitesis, pola pikir dan perilaku keagamaan dan sikap toleransi mereka berubah dari eksklusif ke inklusif, karena dipengaruhi oleh faktor-faktor internal dan eksternal ketika mereka berinteraksi dengan entitas agama, sosial dan budaya masyarakat lainnya. Selanjutnya, sebagai sistesis, pola pikir dan perilaku keagamaan dan sikap toleransi mereka berubah dari inklusif ke pluralis, karena mereka butuh untuk diakui dan ingin beradaptasi secara terbuka (Joachim Wach, 2017; Robertson, 1969).

\section{Kesimpulan}

Proses terpeliharanya kesadaran beragama dalam perilaku sosial masyarakat perdesaan dibentuk oleh dua faktor, yaitu secara internal sebagai sifat alami pada diri setiap orang, sedangkan secara eksternal dipengaruhi oleh lingkungan keluarga, lingkungan sosial dan lingkungan masyarakat umum. Kesemuanya itu dipengaruhi oleh peran tokoh agama yang menumbuhkan norma-norma keagamaan dan sikap toleransi dalam keteladanan perilaku sosial mereka. Terbentuknya kesadaran beragama di kalangan masyarakat tersebut sejalan dengan teori yang dikemukakan oleh Glock and Stark dan Joachim Wach bahwa masyarakat memiliki dimensi keyakinan seperti pengetahuan, keyakinan, ritual, pengalaman, dan menimbulkan munculnya teologi kebebasan beragama di masyarakat. Keadaan lingkungan yang mendukung pluralitas di masyarakat mikro ini dapat menjadi model untuk ditauladani di tempat lain, terutama di Indonesia yang mempunyai masyarakat yang majemuk. Penelitian ini bersifat etnografis mikro di lingkungan perdesaan, sehingga analisisnya juga belum begitu kompleks. Penelitian lanjutan yang lebih berjejaring seperti di perkotaan akan dapat melengkapi kajian etnografi kekinian yang menuntut analisis yang subtil, disebabkan kondisi yang saling berhubungan secara sosio-antropologis.

\section{Referensi}

al-Asqalani, I. H. (2029). Kitab Wabah dan Taun dalam Islam. Jakarta: Turos Pustaka.

Ali, A. (2007). Sosiologi Pendidikan dan Dakwah. Yogyakarta: Cakrawala.

Armini, G. A. (2017). Toleransi Masyarakat Multi Etnis dan Multi Agama dalam Organisasi Subak di Bali. Patanjala: Jurnal Penelitian Sejarah dan Budaya, 5(1), 38. https://doi.org/10.30959/patanjala.v5i1.152

Arwani, W. (2014). Kiai Pesantren dan Kontribusinya dalam Mengembangkan Pluralitas Keberagamaan dan Toleransi di Kabupaten Cirebon. Jurnal Holistik, 15(1).

Aslan, A. (1998). Religious Pluralism in Christian and Islamic Philosophy: The Thought of John Hick and Seyyed Hossein Nasr. London: Psychology Press.

Campbell, R. H., \& Skinner, A. S. (Ed.). (1976). An Inquiry into the Nature and Cause of the Wealth of Nations. Indianapolis: Liberty Press.

Casram, C. (2016). Membangun Sikap Toleransi Beragama dalam Masyarakat Plural. Wawasan: Jurnal Ilmiah Agama dan Sosial Budaya, 1(2), 187-198. https://doi.org/10.15575/jw.v1i2.588

Clark, W. H. (1964). Psychology of Religion. New York: New York University Press.

Coward, H. (1985). Pluralism: Challenge to World Religions. Maryknoll, NY: Orbis Books.

Crome, A. (2019). Cosplay in the pulpit and ponies at prayer: Christian faith and lived religion in wider fan culture. Culture and Religion, 20(2), 129-150. https://doi.org/10.1080/14755610.2019.1624268

Eck, D. L. (2001). A New Religious America: How a "Christian Country" Has Become the World's Most Religiously Diverse Nation. San Francisco: HarperCollins.

Eisenberg, N., Sallquist, J., French, D. C., Purwono, U., Suryanti, T. A., \& Pidada, S. (2009). The relations of majorityminority group status and having an other-religion friend to Indonesian youths' socioemotional functioning. Developmental Psychology, 45(1), 248.

Erwantoro, H. (2012). Sejarah Singkat Kerajaan Cirebon. Patanjala, 4(1), 166-179.

Fossas, A. (2019). Psychological Maturity Predicts Different Forms of Happiness. Journal of Happiness Studies, 20(6), 1933-1952. https://doi.org/10.1007/s10902-018-0033-9

Gumiandari, S., \& Nafi'a, I. (2020). The role of Cirebon Women Ulama in Countering Religious Radicalism. QIJIS 
(Qudus International Journal of Islamic Studies), 8(1), 33. https://doi.org/10.21043/qijis.v8i1.6430

Hariyanto, O. I. B., \& Bsi Bandung, A. (2016). Destinasi Wisata Budaya dan Religi di Cirebon. Jurnal Ecodemica: Jurnal Ekonomi, Manajemen, Dan Bisnis, 4(2), 214-222.

Haryono, S. (2017). Chinese officers in Cirebon. Wacana, Vol. 18, hal. 216-236. Brill Academic Publishers. https://doi.org/10.17510/wacana.v18i1.578

Hasyim, U. (1979). Toleransi dan Kemerdekaan Beragama dalam Islam Sebagai Dasar Menuju Dialog dan Kerukunan Antar Umat Beragama. Surabaya: Bina Ilmu.

Hick, J. (1985). Problems of Religious Pluralism. Houndmills Basingstoke: The Macmillan Press.

Hurlock, E. B. (1980). Psikologi Perkembangan: Suatu Pendekatan Sepanjang Rentang Kehidupan. Jakarta: Erlangga.

Ihsan, A. B. (2009). Menebar Toleransi Menyemai Harmoni (SBY dalam Wacana Perdamaian, Moderatisme dan Keadilan). Bandung: Remaja Rosdakarya.

Joachim Wach. (2017). Sociology of religion. In The Cambridge Handbook of Sociology (Vol. 1). New York: Routledge. https://doi.org/10.1017/9781316418376.030

Koentjaraningrat. (2005). Pengantar Antropologi 1. Jakarta: Rineka Cipta.

Long, A. S., Rahman, Z. A., Razick, A. S., \& Salleh, K. (2017). Muslim socio-culture and majority-minority relations in recent Sri Lanka. J. Pol. E L., 10, 105.

Macacfie, A. L., \& Raphael, D. D. (Ed.). (1982). Theory of Moral Sentiments. Indianapolis: Liberty Press.

Manfaat, B. (2013). Praktik Pendidikan Multikultural di Pondok Pesantren Dar al-Tauhid Cirebon. Holistik Jurnal for Islamic Social Sciences, 14(1). https://doi.org/10.24235/holistik.v14i1.161

Mantu, R. (2015). Bina-Damai dalam Komunitas Pesantren: Sebuah Upaya Counter-Radikalisme. Walisongo Jurnal Penelitian Sosial Keagamaan, 23(1), 131-150. https://doi.org/10.21580/ws.23.1.227

Maryam, S. (2013). Optimalisasi Penggunaan Bahasa Indonesia dan Bahasa Daerah sebagai Modal Sosial dalam Pembangunan Masyarakat Perdesaan. ATIKAN: Jurnal Kajian Pendidikan, 3(1), 45-58.

Maulana, M. A. (2017). Pelaksanaan Toleransi Keberagamaan dalam Proses Pendidikan Agama di Geeta School Cirebon. Oasis: Jurnal Ilmiah Kajian Islam, 1(2), 17-38.

Mikles, N. L. (2019). The power of genres and the project of secularisation: publishing the Gesar epic in contemporary China. Culture and Religion, 20(3), 322-350. https://doi.org/10.1080/14755610.2019.1704423

Muhammad, H. (2011). Mengaji Pluralisme Kepada Mahaguru Pencerahan. Bandung: Mizan.

Narwoko, J. D., \& Suyanto, B. (2007). Sosiologi Teks Pengantar dan Terapan. Jakarta: Prenada Media.

Nursa'adah, N. (2018). Hubungan Antar Umat Beragama di Kota Cirebon Kajian atas Pembentukan Budaya Toleransi pada Alumni Sekolah Cinta Perdamaian 2014-2016. JURNAL YAQZHAN: Analisis Filsafat, Agama dan Kemanusiaan, 4(1). https://doi.org/10.24235/jy.v4i1.3188

Nuruzzaman, M. (2018). Pengaruh Media Sosial (Medsos) Terhadap Perkembangan Paham Radikalisme di Kota Cirebon. Syntax Literate: Jurnal Ilmiah Indonesia, 3(7), 89-98.

Putra, I. E., \& Wagner, W. (2017). Prejudice in interreligious context: The role of metaprejudice and majorityminority status. Journal of Community E Applied Social Psychology, 27(3), 226-239.

Putri, A. W., Wibhawa, B., \& Gutama, A. S. (2015). Kesehatan Mental Masyarakat Indonesia (Pengetahuan dan Keterbukaan Masyarakat Terhadap Gangguan Kesehatan Mental). Prosiding Penelitian Dan Pengabdian Kepada Masyarakat, 252-258. Bandung.

Rachman, B. M. (2010). Argumen Islam untuk Pluralisme. Jakarta: Gramedia Widiasarana Indonesia.

Rakhmat, J. (2003). Psikologi Agama: Sebuah Pengantar. Bandung: Mizan.

Rakhmat, J. (2006). Islam dan Pluralisme, Akhlak al Qur'an Menyikapi Perbedaan. Jakarta: Serambi.

Ramayulis. (2002). Psikologi Agama. Jakarta: Kalam Mulia.

Rescher, N. (2005). Pluralism Against the Demand for Consensus. Oxford: Clarendon Press.

Ritzer, G., \& Goodman, D. J. (2017). Teori Sosiologi Dari Teori Sosiologi Klasik Sampai Perkembangan Mutakhir Teori Sosial Postmodern (ed). Bantul: Kreasi Wacana.

Robertson, R. (1969). Sociology of Religion. Victoria: Penguin Books Australia, Ltd.

Robertson, R. (1992). Globalization: Social Theory and Global Culture. London - New Delhi: Sage Publication.

Ruane, J. (2006). Majority-minority conflicts and their resolution: Protestant minorities in France and in Ireland. Nationalism and Ethnic Politics, 12(3-4), 509-532.

Rubin, D. I. (2019). Navigating the 'space between' the Black/White binary: a call for Jewish multicultural inclusion. Culture and Religion, 20(2), 192-206. https://doi.org/10.1080/14755610.2019.1624267

Setijowati, A. (2010). Sastra dan Budaya Perdesaan dalam Kajian Lintas Media. Surabaya: Airlangga University Press. Sirry, M. A. (2003). Fikih Lintas Agama: Membangun Masyarakat Inklusif-Pluralis. Jakarta: Paramadina.

Soekamto, S. (2003). Sosiologi Suatu Pengantar. Jakarta: Grafindo Persada.

Subaweh, A. M., Sumiyadi, Iskandarwassid, \& Permadi, T. (2020). Fungsi Tradisi Lisan Aurodan dari Tarekat AsySyahadatain Cirebon dalam Kehidupan Komunitas Pemiliknya. tilistika: Jurnal Pendidikan Bahasa dan Sastra, 
13(2), 225-233.

Sumarthana. (1993). Dialog: Kritik dan Identitas Agama. Yogyakarta: Interfidei.

Taher, E. P. (2011). Merayakan Kebebasan Beragama: Bunga Rampai 70 Tahun Djohan Effendi. Jakarta: Democracy Project.

Umam, K. (2018). Mereda Konflik; Menghargai Identitas (studi kasus pada aliran-aliran kepercayaan yang ada di Indramayu). Asketik Jurnal Agama dan Peruban Sosial, 2(2), 163-174.

Umam, K., \& Ghazali, A. M. (2019). Pandangan Tokoh Agama Di Karesidenan Cirebon Dalam Memandang Pluralitas Beragama. NUANSA: Jurnal Penelitian Ilmu Sosial dan Keagamaan Islam, 16(1), 19. https://doi.org/10.19105/nuansa.v16i1.2358

Ural, N. Y., \& Berg, A. L. (2019). From religious emotions to affects: historical and theoretical reflections on injury to feeling, self and religion. Culture and Religion, 20(2), 207-223. https://doi.org/10.1080/14755610.2019.1603168

Wach, J. (1984). The Comparative Study or Religions. Jakarta: Rajawali Press.

Wahid, A., \& Ikeda, D. (2010). Dialog Peradaban untuk Toleransi dan Perdamaian. Jakarta: Gramedia Pustaka Utama. Weber, M. (2009). Sosiologi. Yogyakarta: Pustaka Pelajar.

Wigger, I. (2019). Anti-Muslim racism and the racialisation of sexual violence: 'intersectional stereotyping' in mass media representations of male Muslim migrants in Germany. Culture and Religion, 20(3), $248-271$. https://doi.org/10.1080/14755610.2019.1658609

(C) 2021 by the authors. Submitted for possible open access publication under the terms and conditions of the Creative Commons Attribution (CC BY SA) license (https://creativecommons.org/licenses/by-sa/3.0/). 